This article was downloaded by: [York University Libraries]

On: 12 November 2014, At: 06:26

Publisher: Taylor \& Francis

Informa Ltd Registered in England and Wales Registered Number: 1072954

Registered office: Mortimer House, 37-41 Mortimer Street, London W1T 3J H, UK

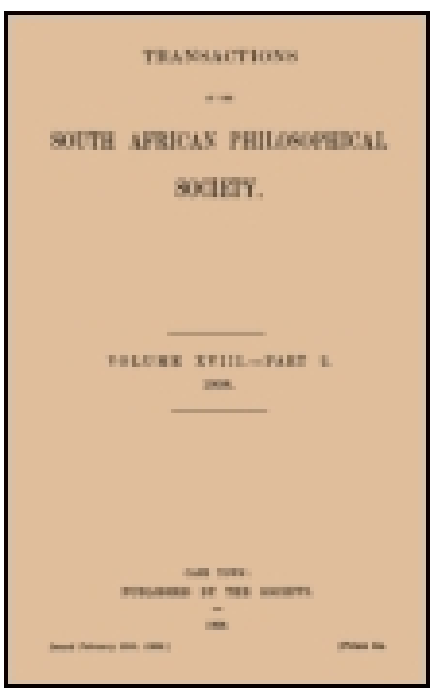

\title{
Transactions of the South African Philosophical Society
}

Publication details, including instructions for authors and subscription information:

http:// www. tandfonline.com/loi/ttrs19

\section{REPORT OF THE PROCEEDINGS}

L. PÉRINGUEY

Published online: $28 \mathrm{~J}$ un 2010.

To cite this article: L. PÉRINGUEY (1890) REPORT OF THE PROCEEDINGS, Transactions of the South African Philosophical Society, 8:1, cii-ciii, DOI: 10.1080/ 21560382.1890.9526284

To link to this article: http:// dx. doi.org/ 10.1080/21560382. 1890.9526284

\section{PLEASE SCROLL DOWN FOR ARTICLE}

Taylor \& Francis makes every effort to ensure the accuracy of all the information (the "Content") contained in the publications on our platform. However, Taylor $\&$ Francis, our agents, and our licensors make no representations or warranties whatsoever as to the accuracy, completeness, or suitability for any purpose of the Content. Any opinions and views expressed in this publication are the opinions and views of the authors, and are not the views of or endorsed by Taylor \& Francis. The accuracy of the Content should not be relied upon and should be independently verified with primary sources of information. Taylor and Francis shall not be liable for any losses, actions, claims, proceedings, demands, costs, expenses, damages, and other liabilities whatsoever or howsoever caused arising directly or indirectly in connection with, in relation to or arising out of the use of the Content.

This article may be used for research, teaching, and private study purposes. Any substantial or systematic reproduction, redistribution, reselling, loan, sub-licensing, systematic supply, or distribution in any form to anyone is expressly forbidden.

Terms \& Conditions of access and use can be found at http://www.tandfonline.com/ page/terms-and-conditions 
cii

\section{REPORT OF THE PROCEEDINGS}

\section{or \\ THE SOUTH AFRICAN PHILOSOPHICAL SOCIETY.}

During the year ending July 31, 1895.

Since the last Annual General Meeting eight Ordinary Meetings have been held. The average attendance of members has been nine, and of visitors four, making an average total of thirteen,

At the Ordinary Meetings four papers have been read on the subjects of 'Mineralogy,' 'Zoology,' 'Meteorology,' and 'Voice Production '; notes on a variety of subjects have been brought before the Society. Brief accounts of these will be printed in the Notes of Proceedings.

A large number of books has been received as exchanges or presentations. A list of these will be published in the Proceedings.

During the year five ordinary members have been elected, two have resigned, and the names of four have been removed for non-payment of their subscriptions; the Society has lost one member by death; the total number of ordinary members is fifty-nine.

The manuscript of the second part of Vol. VIII., 1892-95, is ready for the printer, and the Council has authorized the publication of Part 2 of the 'Descriptive Catalogue of the South African Coleoptera,' which will complete Vol. VII. It is expected that these parts will be shortly in the hands of the members.

L. PÉRINGUEY, General Secretary. 
The Treasurer's Account
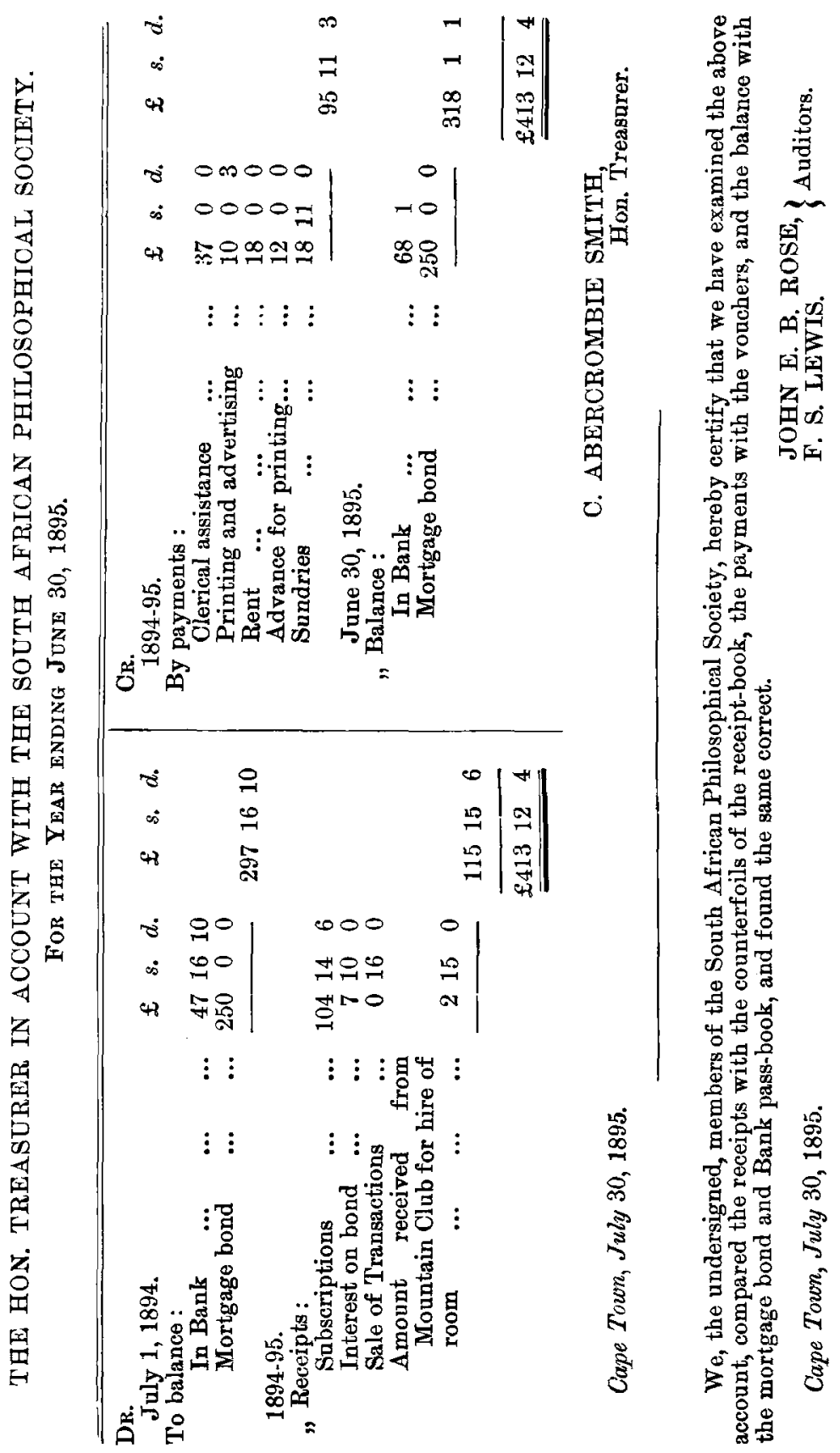